\title{
Raised serum alkaline phosphatase and aspartate transaminase levels in two rheumatoid patients treated with sulphasalazine
}

\author{
M FARR, D P M SYMMONS, AND P A B ACON \\ From the Department of Rheumatology, University of Birmingham, Birmingham B15 2TJ
}

SUMMARY Hepatotoxicity is a rare complication of sulphasalazine therapy in ulcerative colitiso This report describes two rheumatoid patients in whom raised serum levels of liver enzymes. occurred soon after starting sulphasalazine treatment for their arthritis. In both cases the serung enzyme levels returned to normal after stopping the drug. Drug-induced hepatotoxicity should be considered in patients with rheumatoid arthritis (RA) who develop raised serum levels of live enzymes while taking sulphasalazine.

Key words: rheumatoid arthritis, raised liver enzyme levels.

Sulphasalazine (SASP) is a well established drug in the treatment of inflammatory bowel disease. During the last 10 years it has also been found to be an effective second-line drug in rheumatoid arthritis. ${ }^{1-5}$ It has recently been described as a safe alternative to gold therapy, with a much lower incidence of toxicity. ${ }^{6}$ Several adverse reactions have been associated with sulphasalazine and are almost always reversible with discontinuation of the drug. ${ }^{7}$ Hepatotoxicity has not previously been described in RA patients receiving SASP. This report describes hepatotoxicity, as indicated by raised serum alkaline phosphatase and aspartate transaminase levels, in two patients with RA treated with sulphasalazine.

\section{Case reports}

CAS E 1

A 72-year-old lady with a three-year history of seropositive erosive rheumatoid arthritis was started on enteric-coated sulphasalazine because she had persistent active arthritis. She had not previously received a second-line agent or steroids. She had

Accepted for publication 18 April 1985.

Correspondence to Dr Margaret Farr, Department of Rheumatology, Medical School, Birmingham B15 2TJ. been taking piroxicam for four months before starting SASP and this was continued unchange Five days after commencing SASP $(500 \mathrm{mg}$ dailyo she developed epigastric pain, nausea, flatulence and vomiting. This rapidly settled when the drug was stopped. She was advised to modify the drus regimen by taking it on alternate days. Howeve she failed to do this and reverted to the daily dose of $500 \mathrm{mg}$. After a further five days the same symptom recurred. She stopped the SASP but continueg piroxicam. When her condition was reviewed $\underline{\underline{3}}$. month after commencing sulphasalazine her gasi trointestinal problems had completely subsideक general clinical examination was normal, and heos arthritis had improved. Serial blood tests are shown in Table 1. Alkaline phosphatase had risen from 32 to $>2000 \mathrm{U} / \mathrm{l}$ and aspartate transaminase from 14 t $130 \mathrm{U} / \mathrm{l}$ since starting SASP. Electrophoresis of alkaline phosphatase isoenzymes showed the rise to be due to the liver isoenzyme only. Hepatitis $B$ surface antigen $(\mathrm{HBsAg})$ was negative by radioin $\tilde{-}$ munoassay. The rise in liver enzymes was not associated with jaundice, fever, or any other abnof mal signs or symptoms, and at this stage she felt wed and her arthritis had improved. During the next month her serum alkaline phosphatase level fell to $723 \mathrm{U} / \mathrm{l}$ and aspartate transferase to $18 \mathrm{U} / \mathrm{l}$. After 3 \% 
Table 1 Serum levels in patients 1 and 2 of alkaline phosphatase, aspartate transaminase, hilirubin, and haemoglobin (Hb) and the ervthrocyte sedimentation rate (ESR) during treatment with sulphasalazine (SASP)

\begin{tabular}{|c|c|c|c|c|c|c|}
\hline $\begin{array}{l}\text { Time } \\
\text { (weeks) }\end{array}$ & $\begin{array}{l}S A S P \\
\text { (mg) }\end{array}$ & $\begin{array}{l}\text { Alkaline } \\
\text { phosphatase } \\
\text { (UII) }\end{array}$ & $\begin{array}{l}\text { Aspartate } \\
\text { transaminase } \\
\text { (UI) }\end{array}$ & $\begin{array}{l}\text { Bilirubin } \\
\text { (ụmolil) }\end{array}$ & $\begin{array}{l}H b \\
(g / d l)\end{array}$ & $\begin{array}{l}E S R \\
(m m / h)\end{array}$ \\
\hline \multicolumn{7}{|l|}{ Paticnt 1} \\
\hline 0 & 500 & 327 & 14 & 5 & 11.2 & 79 \\
\hline 4 & & $>2(40)$ & 130 & 12 & $12 \cdot 3$ & 47 \\
\hline 8 & & 723 & 18 & 5 & $12 \cdot 7$ & 75 \\
\hline 12 & & 586 & 14 & 5 & 一 & - \\
\hline 16 & & 384 & 13 & 6 & $10 \cdot 4$ & 90 \\
\hline \multicolumn{7}{|l|}{ Paticnt 2} \\
\hline 0 & 500 & 352 & 20 & 9 & $10 \cdot 3$ & 33 \\
\hline 1 & 1000 & 646 & 23 & 6 & 9.6 & 43 \\
\hline 3 & & 745 & 43 & 6 & $10 \cdot 1$ & 36 \\
\hline 4 & & 562 & 19 & 7 & - & - \\
\hline 5 & & 488 & 23 & 9 & $10 \cdot 6$ & 35 \\
\hline Normal range & & $70-300$ & $5-30$ & $1-26$ & $11 \cdot 5-14 \cdot 5$ & $(1-20$ \\
\hline
\end{tabular}

months the alkaline phosphatase had fallen to 384 $\mathrm{U} / \mathrm{l}$ and aspartate transferase to $13 \mathrm{U} / \mathrm{l}$; she remained well.

C A S E 2

A 71-year-old lady with a 10-year history of seropositive erosive rheumatoid arthritis was started on sulphasalazine to control her active joint disease. Previously she had received gold in 1977 and 1981 but had developed a rash on both occasions. She had not received any other second-line antirheumatic drugs and was currently taking naproxen $500 \mathrm{mg}$ twice daily, indomethacin suppository $100 \mathrm{mg}$ at night, and temazepam $10 \mathrm{mg}$ at night. Her general health was good.

Two days after starting enteric-coated sulphasalazine at a dose of $500 \mathrm{mg}$ daily her alkaline phosphatase started to rise (Table 1). In line with our routine clinical practice the dose of sulphasalazine was increased to $1000 \mathrm{mg}$ daily, one week after therapy was started. The alkaline phosphatase continued to rise until the drug was stopped one week later and then fell again over the next two weeks. Electrophoresis of the isoenzymes of alkaline phosphatase showed the rise to be due to the liver isoenzyme only. The patient remained well during this time and did not have any jaundice, fever, or hepatomegaly, though she did have an asymptomatic Escherichia coli urinary tract infection. An ultrasound of the liver and gall bladder showed no abnormality. None of her other medications were changed immediately before the rise in alkaline phosphatase and only the sulphasalazine was stopped.

\section{Discussion}

Hepatotoxicity associated with sulphasalazine when used to treat ulcerative colitis has been reported infrequently. The Committee on Safety of Medicines has received 323 adverse reaction reports due to SASP therapy in inflammatory bowel disease since 1964, only 11 of which involved liver disorders. Hepatotoxicity has not been previously reported with SASP used in the treatment of rheumatoid arthritis. It has, however, been associated with other second-line antirheumatic drugs, e.g., penicillamine $^{8}$ and gold. ${ }^{9}$

Abnormalities of liver enzymes have been reported in active rheumatoid disease. Kendall et al. in $1970^{10}$ found that alkaline phosphatase was raised in $26 \%$ of rheumatoid patients and that it was also higher in more active disease. Aspartate transaminase has also been reported to be raised in some RA patients. ${ }^{11}$ Although both the patients in this report had active rheumatoid disease, with liver enzymes in the upper part of the normal range before treatment, there is no doubt that the enzyme levels markedly increased after SASP therapy and fell again when the drug was withdrawn. The rise was not associated with an exacerbation of their arthritis. The rise in liver enzymes occurred within a month of starting SASP in both cases. This pattern is consistent with reports of hepatic complications due to SASP treatment in ulcerative colitis which usually occur within 14 days of starting treatment. $^{1213}$ There have, however, been isolated reports of late onset hepatotoxicity associated with this drug. ${ }^{1+}$ The rise in liver enzyme levels in our 
patients was detected early and fell again after withdrawal of the drug. but hepatotoxicity may progress to acute focal hepatocellular necrosis ${ }^{15}$ or chronic granulomatous hepatitis. ${ }^{16}$ The nausea, vomiting. flatulence, and abdominal pain experienced by patient 1 are well recognised early side effects of SASP due to the sulphonamide component and may not be directly associated with the rise in liver enzymes.

The mechanism of SASP associated reactions in these two patients is probably due to a hypersensitivity reaction resulting from the sulphapyridine moiety of SASP, ${ }^{12-16}$ and it may progress to cholestatic jaundice and hepatic injury. Thus early hepatotoxicity should be added to the list of possible complications of SASP therapy in RA. It is important to monitor liver function to detect and reverse this adverse reaction promptly.

We are grateful to Dr Linda Becley and Miss R Lawrence for their help. MF receives financial support from the Arthritis and Rhcumatism Council for Research.

\section{References}

1 McConkey B. Amos R S. Durham S. Forster P J G. Hubball S. Walsh L. Sulphasalazine in rheumatoid arthritis. Br Med J 1980; 280: $442-4$.

2 Bird H A, Dixon J S, Pickup M E A. A biochemical assessment of sulphasalazine in rheumatoid arthritis. $J$ Rheumatol 1982: 9: 36-46.

3 Neumann V C, Grindulis K A. Huball S, McConkey B. Wright V. Comparison between penicillamine and sulphasalazine in rheumatoid arthritis: Leeds-Birmingham Trial. Br Med J 1983; 287: 1099-102.
4 Pullar T. Hunter J A. Capell H A. Sulphasalazine in rheumatoid arthritis: a double blind comparison of sulphasalazine wite. placebo and sodium aurothiomalate. $B r$ Med $J$ 1983: 287: $1102-4$.

5 Farr M. Tunn E. Crockson A P. Bacon P A. The long terrf effects of sulphasalazine in the treatment of rheumatoid arthritio and a comparative study with penicillamine. Clin Rheumatef 1984: 3: 473-82.

6 Bax D E. Amos R S. Sulphasalazine: a safe. effective agent fo prolonged control of rheumatoid arthritis. A comparison wit sodium aurothiomalate. Ann Rheum Dis 1985: 44: 194-9.

7 Pullar T. Capell H A. Sulphasalazine: a 'new' antirheumati drug. Br J Rheum 1984: 13: 26-34.

8 Rosenbaum J, Katz W A. Schumacher H R. Hepatotoxiciti associated with use of D-penicillamine in rheumatoid arthritis Ann Rheum Dis 1980): 39: 152-4.

9 Keen W F. Anastassiades T P. Long term chrysotherapy Incidence of toxicity and efficacy during sequential time periods. Arthritis Rheum 1979; 22: 495-501.

10 Kendall M J. Cockel R. Becker J. Hawkins C F. Raised serum alkaline phosphatase in rheumatoid disease. Ann Rheum Dis 1970: 29: 537-40.

11 Wilding. P, Kendall M J, Holder R. Grimes J A. Farr M. Thळ influence of drugs and disease activity on biochemical an $\Phi$ hacmatological data in rheumatoid arthritis. (lin (him Acra 1975: 64: 185-94.

12 Losek J D. Werlin S L. Sulphasalazine hepatotoxicity. Am J I) Z Child 1981: 135: 1070-2.

13 Sotolongo R P. Neepe L I. Rudzki C. et al. Hypersensitivit reaction to sulphasalazine with severe hepatotoxicity. Gastroe, terology 1978: 7: 95-9.

14 Lennard T W J. Farndon J R. Sulphasalazine hepatotoxfit after 15 years" successful treatment in ulcerative colitis. $B r \mathbb{M}$ J 1983: 287: 96.

15 Dujovne C A. Chan C H. Zimmerman H J. Sulphonatide hepatic injury. $N$ Engl J Med 1967; 277: 785-8.

16 Espiritu C R. Kim T S. Levine R A. Granulomatous hepatit associated with sulphadimethioxine hypersensitivity. JAM 1967: 202: $985-8$

\section{Clinical vignette}

\section{Knee pain}

Otherwise inexplicable knee pain is often associated with exquisite tenderness over the lower pole of the medial ligament and responds well to regular knee-bend exercises of the pre-ski variety. If the feet are flat, intrinsic foot exercises shouleg be practised as well. 